\title{
USE OF ANODIC STRIPPING VOLTAMMETRY IN PREDICTING TOXICITY OF COPPER IN RIVER WATER
}

\author{
ZiJian Wang,* Shengbiao Huang, and Qing LiU \\ State Key Laboratory of Environmental Aquatic Chemistry, Research Center for Eco-Environmental Sciences, Shuangqing Road 18, \\ Haidian District, Beijing, 100085, China
}

(Received 30 July 2001; Accepted 4 March 2002)

\begin{abstract}
The labile concentration and toxicity of $\mathrm{Cu}$ as influenced by alkalinity and different concentrations of ethylenediaminetetraacetic acid (EDTA) and naturally derived fulvic acid (FA) were determined by bioassays carried out in the culture media for Daphnia magna (D. magna). The labile concentration of $\mathrm{Cu}$ was obtained by differential pulse anodic stripping voltammetry with a double-acidification method (DAM-DPASV). Changes in water alkalinity did not affect the labile concentration of $\mathrm{Cu}$, but increase in alkalinity did reduce the mortality of D. magna. In the presence of EDTA and FA, both labile concentration of Cu and mortality were reduced. By excluding $\mathrm{Cu}$-carbonate complexes from the labile concentration, a bioavailable concentration of $\mathrm{Cu}$ $\left(\left[\mathrm{Cu}^{*}\right]\right)$ was obtained and was used to predict the acute toxicity of $\mathrm{Cu}$ on $D$. magna. For natural waters, the labile concentration of $\mathrm{Cu}$ was measured by DAM-DPASV, and [ $\left.\mathrm{Cu}^{*}\right]$ was calculated using MINTEQ A2 software (developed by the U.S. Environmental Protection Agency) based on the anion composition of waters. This procedure was tested for waters and sediment elutriates sampled from the Le An River (Jiangxi Province, China) that were severely polluted by the discharges from a copper mine. The results showed that $\left[\mathrm{Cu}^{*}\right]$ was a good indicator for $\mathrm{Cu}$ toxicity and could be used under field conditions.
\end{abstract}

Keywords-Copper speciation Acute toxicity Daphnia magna Natural waters

\section{INTRODUCTION}

Bioavailability and toxicity of trace metals to aquatic organisms depend on the physical and chemical speciation of the metals [1]. Therefore, the speciation of a metal, rather than its total concentration, is the key for understanding its effect on the biota [2]. Previous studies on several metals and varieties of aquatic organisms have demonstrated that the response of organisms to metals could be modeled by using their free-ion activity [3-5]. To rationalize these experimental results and to explain what was perceived as "the universal importance of free-ion activities in determining the biological effect of all cationic trace metal," Morel [5] formulated the free-ion activity model (FIAM) for metal-organism interaction. The FIAM has generally been interpreted to imply that a constant degree of biological effect will occur at a constant chemical activity of the free ion of a metal for divalent transitionmetal cations. These studies suggest that the concentration of free-ionic metal is the key factor in determining the toxicity. It might be tempting to conclude that the free ion alone is responsible for the observed toxicities, but this does not appear to be supported by the previously published work [6]

Free-ion activity does not appear to be a good predictor of toxicity under certain water-quality conditions (e.g., water hardness), and it does not explain competition of the metal ion in question with other cations [7]. The formation of a biotic-ligand model (BLM), a recent surface-interaction model of metal binding to fish gill, simultaneously incorporates metal speciation with its toxicity and competition between the metal ion under study and other cations [8,9]. Thus, adopting the BLM model could help to predict acute toxicity of $\mathrm{Cu}$ to fish on a mechanistic basis and under various conditions of water hardness. However, several factors should be investigated over

* To whom correspondence may be addressed (wangzj@mail.rcees.ac.cn). time that may improve the model's predictability and our understanding of its strengths or limitations [10]. For example, in testing the model's ability to predict $\mathrm{Cu}$ toxicity, it was assumed that the dissolved organic carbon (DOC) was $10 \%$ (w/w) humic acid and that the conditional stability constant of $\mathrm{Cu}$ with humic acid was not considered to be a site-specific parameter [10].

Anodic stripping voltammetry (ASV) is a powerful technique for the study of trace element speciation, which can be used to provide speciation information regarding the labile/ inert discrimination [11]. Fulvic acid (FA) binds with $\mathrm{Cu}$, thereby making it no longer labile in ASV measurements. When $\mathrm{Cu}$ is bound to FA in natural aquatic environments, it is no longer available for biota. This procedure thus provides a good approximation of labile metal speciation. This leads to the deposition process of labile metal on the surface of an electrode approximating as closely as possible the kinetics of its uptake processes by the cells of organisms [12,13]. The correlation between ASV-labile concentrations of $\mathrm{Cu}$ and toxicity derived from bioassay may, therefore, be useful in predicting its toxicity. However, some aquatic components, such as FA, can affect the stripping current not only through affecting aqueous $\mathrm{Cu}$ species but also through adsorbing organic components on the surface of an electrode (e.g., mercury drop). To avoid interference by organic components on stripping current, a double-acidification process is recommended [14]. By assuming that strong organic complexes of $\mathrm{Cu}$ are neither labile nor bioavailable, leading to acute toxicity [1], and that only part of inorganic complexes are bioavailable or toxic, the acute toxicity of $\mathrm{Cu}$ in natural water can be predicted. This prediction will be based on measurements obtained by differential pulse ASV with the double-acidification method (DAMDPASV) and calculated by a MINTEQ A2 software (developed by the U.S. Environmental Protection Agency) and will exclude $\mathrm{Cu}$-carbonate complexes from labile speciation of $\mathrm{Cu}$. 

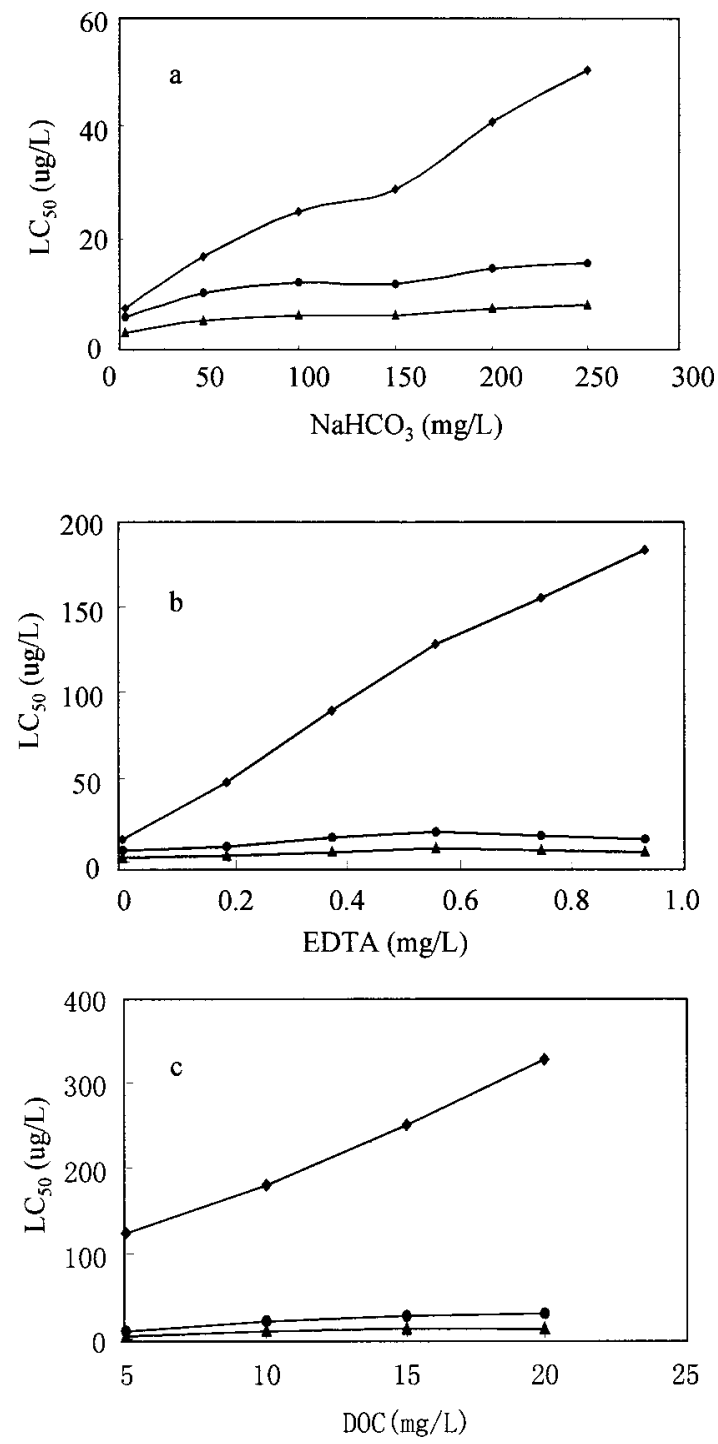

Fig. 1. Median lethal concentrations (LC50s) expressed as total $\mathrm{Cu}$ concentrations $(\diamond)$, free $\mathrm{Cu}$ concentrations $(\boldsymbol{\Delta})$, and bioavailable $\mathrm{Cu}$ (O) as a function of ligand concentrations. Three different ligands were used: (a) $\mathrm{NaHCO}_{3}$, (b) ethylenediaminetetraacetic acid (EDTA), and (c) fulvic acid (FA) expressed as dissolved organic carbon (DOC).

In the present study, we have developed the approach and a model to predict the acute toxicity of $\mathrm{Cu}$ on Daphnia magna.

\section{MATERIALS AND METHODS}

\section{Sampling and test solution preparations}

Nine samples were taken from the Le An River. The sampling sites were chosen along the downstream from Haikou to Panlong Temple. Site L04 was $20 \mathrm{~km}$ downstream from site L01, where the largest open-cast $\mathrm{Cu}$ mine in China (Dexing Copper mine) is located and whose discharges flow into the Le An River at the convergence with the Dawu River. Site L07 was $50 \mathrm{~km}$ downstream and at the convergence with the Jihui River (39 km long), which is another metal-polluted river with several small sulfide mines and smelters. Site L09 was $230 \mathrm{~km}$ downstream and in the delta area of Poyang Lake, the largest freshwater lake in China. The metal pollution and the ecological consequences in the Le An River have been reported previously [15-17].

A 20-L water sample was filtered through a Millipore 0.45 -

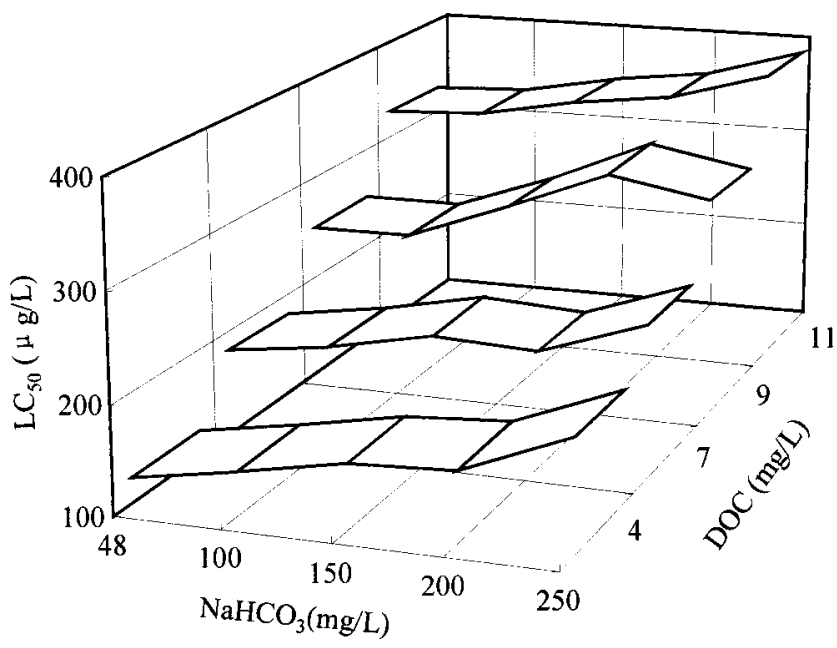

Fig. 2. Toxicity of $\mathrm{Cu}$ to Daphnia magna as a function of alkalinity (expressed as $\mathrm{NaHCO}_{3}$ ), fulvic acid, and dissolved organic carbon (DOC). The median lethal concentrations (LC50s) are expressed in terms of total $\mathrm{Cu}$ concentrations.

$\mu \mathrm{m}$ filter (Bedford, MA, USA) and collected in a precleaned polyethylene bottle. The samples were stored at $4{ }^{\circ} \mathrm{C}$ and used within one week. Sediment samples were collected from the same locations on the Le An River and at the same time as the water samples. Sediment samples were stored at $4^{\circ} \mathrm{C}$ in the dark and used within four weeks. Sediment elutriate was prepared by extracting wet sediment with four volumes of distilled water and shaking at $200 \mathrm{rpm}$ for $12 \mathrm{~h}$, followed by isolation of the aqueous fraction by centrifugation at 2,500 $\mathrm{g}$ for $30 \mathrm{~min}$ at $4^{\circ} \mathrm{C}$. After sampling, concentration of DOC was measured by high-temperature combustion method on a total organic carbon analyzer (TOC; Phoenix 8000; Tekman Dokrmann, Cincinnati, OH, USA). Major anions were measured by ion chromatography (Series 4500i, Dionex, San Francisco, CA, USA). The FA was extracted and separated from Le An River sediment and purified according to the method developed by Wang [18].

Stock solution of $\mathrm{Cu}$ was prepared in double-distilled, deionized water $\left(\mathrm{dddH}_{2} \mathrm{O}\right)$ from analytical $\mathrm{Cu}$ sulfate and acidified with $\mathrm{HNO}_{3}\left(10^{-4} \mathrm{~mol} / \mathrm{L}\right)$. The test solutions were prepared by diluting the stock solution with reconstituted water con-

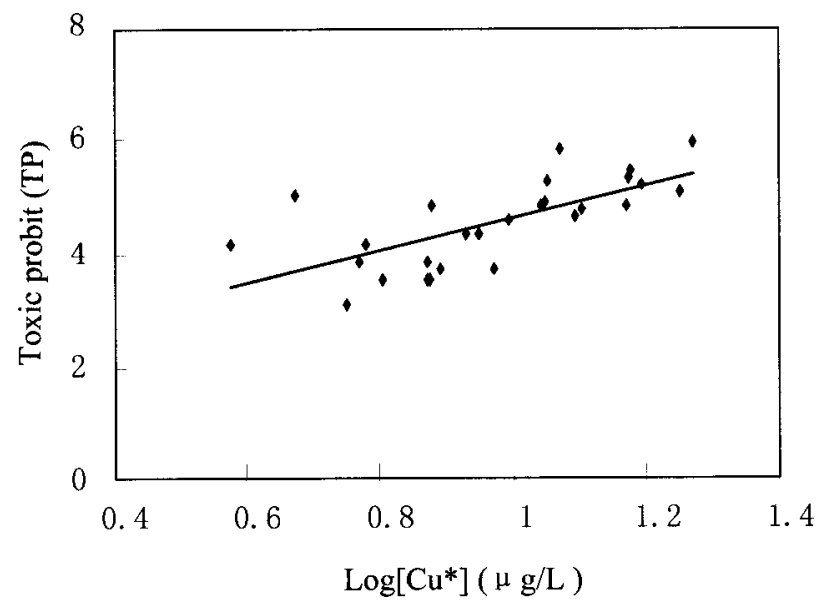

Fig. 3. Relationship between toxic probit (TP) and logarithmic concentration of bioavailable $\mathrm{Cu}\left(\left[\mathrm{Cu}^{*}\right]\right)$. Toxic data $(n=28)$ were collected from Figures 1 and 2. 
taining $\mathrm{NaHCO}_{3}(48 \mathrm{mg} / \mathrm{L}), \mathrm{MgSO}_{4}(30 \mathrm{mg} / \mathrm{L}), \mathrm{CaSO}_{4} \cdot 2 \mathrm{H}_{2} \mathrm{O}$ $(30 \mathrm{mg} / \mathrm{L})$, and $\mathrm{KCl}(2 \mathrm{mg} / \mathrm{L})$ before use. The test solutions of different alkalinity (expressed as $\left[\mathrm{NaHCO}_{3}\right]$ ) or containing different amounts of ethylenediaminetetraacetic acid (EDTA), and/or FA were prepared by adding appropriate amounts of stock solutions of $\mathrm{NaHCO}_{3}, \mathrm{Na}$-EDTA, FA, and $\mathrm{Cu}$ to the reconstituted water. Concentration of FA $(\mathrm{mg}-\mathrm{C} / \mathrm{L})$ was measured after filtering through $0.45-\mu \mathrm{m}$ membrane filters, and TOC was measured. All test solutions were buffered with $\mathrm{N}$ [2-hydroxyethyl]-piperazine- $\mathrm{N}^{\prime}$-[2-ethanesulfonic acid] (HEPES; Sino-American Biotec, Beijing, China), and the $\mathrm{pH}$ was adjusted with $\mathrm{NaOH}(0.5 \mathrm{~mol} / \mathrm{L})$ to 6.8 before use. In the test solutions, the concentration of HEPES was $0.006 \mathrm{~mol} / \mathrm{L}$. It has been demonstrated that HEPES, when present in concentrations of less than $10 \mathrm{mmol} / \mathrm{L}$, forms weak complexes with copper and does not interfere with copper speciation in solution [19]. The test solution was allowed to equilibrate for at least $24 \mathrm{~h}$ at a constant temperature of 23 mean \pm SEM $1^{\circ} \mathrm{C}$ before DAM-DPASV measurements and bioassay.

The DAM-DPASV measurements were performed to obtain the labile concentrations of $\mathrm{Cu}$. Bioassays using D. magna were performed to obtain the acute toxicity in the test solutions and in river water samples and sediment elutriates.

\section{Chemical measurements}

The DAM-DPASV measurements were performed with a Model 303A static mercury drop electrode assembly plus a Model 303 stirrer coupled with a polarographic analyzer (Model 263; EG\&G, Princeton, NJ, USA). The mercury electrode used as the working electrode was washed with $10 \%$ nitric acid and $\mathrm{dddH}_{2} \mathrm{O}$ twice. To avoid metal contamination, all plastic and glassware were washed with 1:1 (w/w) nitric acid followed by $\mathrm{dddH}_{2} \mathrm{O}$. In all experiments, sodium nitrate $(0.1$ $\mathrm{mol} / \mathrm{L})$ was used to maintain a constant ionic strength of the solutions. The specific setting used for the differential pulse mode was as follows: scan rate, $10 \mathrm{mV} / \mathrm{s}$; drop size, medium; pulse height, $50 \mathrm{mV}$; step time, $0.3 \mathrm{~s}$; scan width, $2 \mathrm{mV}$; initial potential, $-1.0 \mathrm{~V}$; and final potential, $+0.15 \mathrm{~V}$ versus $\mathrm{Ag}$ $\mathrm{AgCl}$. A rotation rate of 4,000 rpm was used. During each step of titration, the electrode surface was wiped clean with plain filter paper and rinsed with ddd $\mathrm{H}_{2} \mathrm{O}$. Measurements were carried out in $10 \mathrm{ml}$ of working solution in a cell at $23 \pm 1{ }^{\circ} \mathrm{C}$. Then, the samples were degassed with oxygen-free $\mathrm{N}_{2}$ for 15 min. Samples were plated at $-1.0 \mathrm{~V}$ for $300 \mathrm{~s}$, followed by a 15 -s quiescent period before the film was stripped by scanning the potential in the positive direction, using the differential pulse mode, to a final potential of $+0.15 \mathrm{~V}$. The doubleacidification procedure involved a deposition at $\mathrm{pH} 6.8$ for 20 $\mathrm{s}$; then, before completion of the 300-s deposition and with the cell circuit uninterrupted, $50 \mu \mathrm{l}$ of $\mathrm{HNO}_{3}(5 \mathrm{~mol} / \mathrm{L})$ were added through the standard addition port. After recording the stripping voltammogram, a new run was initiated for the same solution; this time, the $\mathrm{pH}$ during both deposition and stripping runs was adjusted to 2.0. The percentage of labile $\mathrm{Cu}$ in the total $\mathrm{Cu}$ could be obtained as

$$
\text { Labile-Cu }(\%)=100\left[1-\left(c_{1}-c_{2}\right) / c_{\mathrm{T}}\right]
$$

where $c_{1}$ is the concentration of $\mathrm{Cu}$ measured with deposition

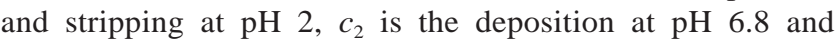
stripping at $\mathrm{pH} \mathrm{2}$, and $c_{\mathrm{T}}$ is the total $\mathrm{Cu}$ concentration. The calibration was carried out at $\mathrm{Cu}$ concentrations ranging from 0.5 to $20 \mu \mathrm{g} / \mathrm{L}$ in 10 increments in reconstituted water $\left(\mathrm{NaNO}_{3}\right.$, $0.1 \mathrm{~mol} / \mathrm{L}$; HEPES, $0.06 \mathrm{~mol} / \mathrm{L})$. For each sample, triplicates

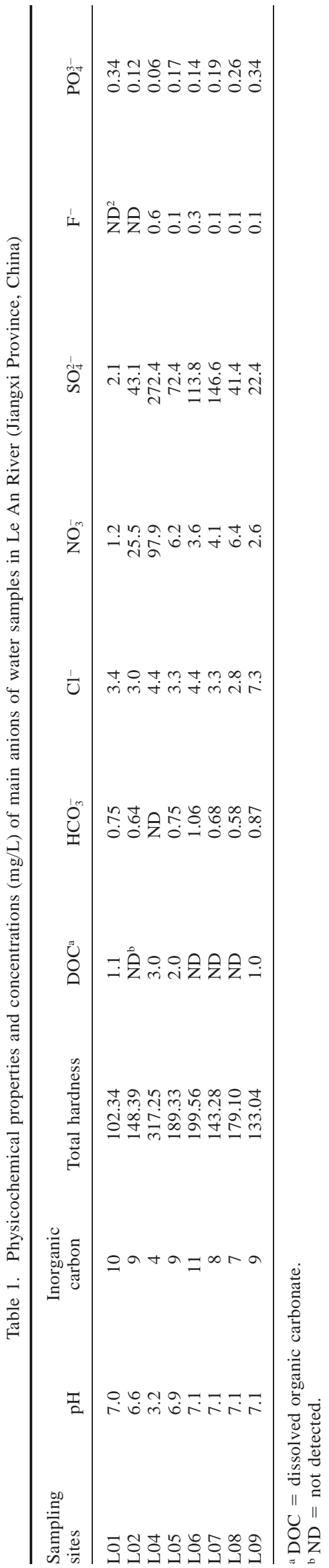


measurements were taken, and the labile concentration of $\mathrm{Cu}$ was calculated from the calibration curve. Precision for measurements in DAM-DPASV was $\pm 9 \%$ relative standard deviation for test solution containing $\mathrm{Cu}$ at $2 \mu \mathrm{g} / \mathrm{L}(n=6)$.

The total concentrations of dissolved $\mathrm{Cu}, \mathrm{Pb}$, and $\mathrm{Zn}$ in water samples were measured in acidified filtrates by a graphite furnace atomic absorption spectrometer (Model 3100; PerkinElmer, Norwalk, CT, USA). Concentrations of $\mathrm{Cu}, \mathrm{Pb}$, and $\mathrm{Zn}$ in sediments were measured by graphite furnace atomic absorption spectrometer after microwave digestion [20].

\section{Acute toxicity bioassays}

Bioassays for the acute toxicity of $\mathrm{Cu}$ were performed on D. magna. The static bioassay procedure described by the U.S. Environmental Protection Agency guideline for test chemicals was adapted with triplicate samples [21]. The test species $D$. magna was obtained from the Institute of Hydrobiology (Wuhan, China) and adapted in the laboratory for a period of one month. Healthy D. magna, not more than $24 \mathrm{~h}$ old at the beginning of the test, did not have to be fed during the test. Ten animals were used for each concentration in the $50 \mathrm{ml}$ of test solution in a $100-\mathrm{ml}$ beaker. The test temperature was 23 $\pm 1^{\circ} \mathrm{C}$. For the validity of the test, no more than $10 \%$ immobility (or mortality) of the animals was accepted as the control. The dissolved oxygen concentration at the end of the test was maintained at $60 \%$ or greater air saturation.

Data on 96-h median lethal concentration (LC50) determined by the immobilization (or mortality) tests were used as acute toxicity data. The LC50s and associated $90 \%$ confidence intervals for each replicate toxicity bioassay were calculated by trimmed Spearman-Karber analysis [22]. Toxic probit (TP) was transformed from mortality according to the method of probit unit [23]. Regression analysis was performed using Sigmaplot $^{\circledR} 4.0$ (SPSS, Chicago, IL, USA).

\section{$\mathrm{Cu}$ speciation}

The concentrations of different $\mathrm{Cu}$ species present in test solutions, other than that containing FA, could be calculated from the spiked concentrations of $\mathrm{Cu}$, the composition of the reconstituted water, and the known stability constants of $\mathrm{Cu}$ complexes using MINTEQ A2 (Ver 4.1). For water samples and test solution containing FA, inorganic $\mathrm{Cu}$ speciation could be calculated from the labile concentration of $\mathrm{Cu}$, assuming that $\mathrm{Cu}$ associated with strong organic ligands was nonlabile in DPASV measurements and that $\mathrm{Cu}$ associated with weak organic ligands was negligible in comparison to inorganic complexes of similar stability constants. This hypothesis is valid because DPASV has long been used to obtain the apparent stability constants of $\mathrm{Cu}$ with FA, both by metal titration and by proton titration [24].

\section{RESULTS AND DISCUSSION}

Deriving the expression for the relationship between $\mathrm{Cu}$ speciation and acute toxicity

Influences of alkalinity and different concentrations of EDTA and FA derived from the Le An River on the acute toxicity of $\mathrm{Cu}$ to D. magna are shown in Figure 1. Addition of $\mathrm{NaHCO}_{3}$, EDTA, and FA to test solutions inhibited significantly the $\mathrm{Cu}$ toxicity. Similar observations on the inhibition effects of $\mathrm{Cu}$ to different organisms have been reported in previous studies [25].

The toxicity of $\mathrm{Cu}$ to $\mathrm{D}$. magna increased with spiked concentrations of $\mathrm{Cu}$ and decreased with spiked concentrations of 
$\mathrm{NaHCO}_{3}$, EDTA, and FA. This suggests that the complexation of $\mathrm{Cu}$ with $\mathrm{HCO}_{3}^{-}$, EDTA, and FA reduced the free-ion concentration of $\mathrm{Cu}$ in the aqueous phase according to the FIAM model, thereby reducing the potential of $\mathrm{Cu}$ uptake by the organisms. Thus, $\mathrm{Cu}$, when present in the complex form with $\mathrm{HCO}_{3}{ }^{-}$, EDTA, and FA, could be considered as nonbioavailable or nontoxic.

When $\mathrm{NaHCO}_{3}$ was spiked into the reconstituted water (Fig. 1a), the dominant species of $\mathrm{Cu}$ were $\mathrm{Cu}^{2+}, \mathrm{CuOH}^{+}$, $\mathrm{Cu}(\mathrm{OH})_{2} \mathrm{aq}, \mathrm{CuCO}_{3} \mathrm{aq}, \mathrm{CuHCO}_{3}{ }^{+}, \mathrm{CuCl}^{+}, \mathrm{CuCl}_{2}$, and $\mathrm{CuSO}_{4}$ aq. Under constant $\mathrm{pH}$, the decrease in toxicity was due to the increase of $\mathrm{CuCO}_{3}$ aq and $\mathrm{CuHCO}_{3}{ }^{+}$. The linear regression between LC50 ( $\mu \mathrm{g} / \mathrm{L})$ and concentration of $\mathrm{NaHCO}_{3}(\mathrm{mg} /$ L) could be expressed as

$$
\begin{gathered}
\mathrm{LC} 50(\mu \mathrm{g} / \mathrm{L})=0.12\left[\mathrm{NaHCO}_{3}(\mathrm{mg} / \mathrm{L})\right]+12.22 \\
\left(r^{2}=0.9796, n=6\right)
\end{gathered}
$$

When EDTA was spiked into the reconstituted water (Fig. 1b), the dominant species of $\mathrm{Cu}$ were $\mathrm{Cu}^{2+}, \mathrm{CuOH}^{+}$, $\mathrm{Cu}(\mathrm{OH})_{2} \mathrm{aq}, \mathrm{CuCO}_{3} \mathrm{aq}, \mathrm{CuHCO}_{3}{ }^{+}, \mathrm{CuCl}^{+}, \mathrm{CuCl}_{2}, \mathrm{CuSO}_{4} \mathrm{aq}$, and $\mathrm{Cu}$-EDTA complexes. When the mole concentration of EDTA was greater than that of $\mathrm{Cu}, \mathrm{Cu}$ speciation other than $\mathrm{Cu}$-EDTA could be negligible. Under constant $\mathrm{pH}$ and alkalinity, the decrease in toxicity was likely due to the increase in $\mathrm{Cu}$-EDTA concentration. The linear regression between LC50 $(\mu \mathrm{g} / \mathrm{L})$ and concentration of EDTA $(\mathrm{mg} / \mathrm{L})$ could be expressed as

$$
\begin{gathered}
\operatorname{LC50}(\mu \mathrm{g} / \mathrm{L})=234.63[\operatorname{EDTA}(\mathrm{mg} / \mathrm{L})]+12.85 \\
\left(r^{2}=0.9926, n=6\right)
\end{gathered}
$$

When FA was spiked into the reconstituted water (Fig. 1c), the dominant species of $\mathrm{Cu}$ were $\mathrm{Cu}^{2+}, \mathrm{CuOH}^{+}, \mathrm{Cu}(\mathrm{OH})_{2} \mathrm{aq}$, $\mathrm{CuCO}_{3} \mathrm{aq}, \mathrm{CuHCO}_{3}{ }^{+}, \mathrm{CuCl}^{+}, \mathrm{CuCl}_{2}, \mathrm{CuSO}_{4} \mathrm{aq}$, and $\mathrm{Cu}-\mathrm{FA}$ complexes. The decrease in toxicity was due to the increase in $\mathrm{Cu}-\mathrm{FA}$ concentration. The linear regression between LC50 $(\mu \mathrm{g} / \mathrm{L})$ and concentration of FA $(\mathrm{mg} / \mathrm{L})$ could be expressed as $\mathrm{LC} 50(\mu \mathrm{g} / \mathrm{L})=16.52[\mathrm{FA}(\mathrm{mg} / \mathrm{L})]+17.81$

$$
\left(r^{2}=0.9919, n=4\right)
$$

For test solutions in which both $\mathrm{NaHCO}_{3}$ and FA were present, LC50s under different concentrations of $\mathrm{NaHCO}_{3}$ and FA were obtained, and the results are shown in Figure 2. By multiregression analysis, the relationship between LC50 and concentrations of $\mathrm{NaHCO}_{3}$ and FA could be expressed as

$$
\begin{aligned}
\operatorname{LC} 50(\mu \mathrm{g} / \mathrm{L})= & 17.55[\mathrm{FA}(\mathrm{mg} / \mathrm{L})] \\
& +0.21\left[\mathrm{NaHCO}_{3}(\mathrm{mg} / \mathrm{L})\right]+11.79
\end{aligned}
$$

The intercept in Equation 1 represents the bioavailable concentration of $\mathrm{Cu}$ that causes the LC50 for D. magna, which should be $12.22 \mu \mathrm{g} / \mathrm{L}$. Equations 2 and 3 indicate that the LC50s for $\mathrm{Cu}$ in reconstituted water containing $48 \mathrm{mg} / \mathrm{L}$ of $\mathrm{NaHCO}_{3}$ in absence of EDTA or FA should be 12.85 and 17.81 $\mu \mathrm{g} / \mathrm{L}$, respectively. If the influence of carbonate is excluded, the bioavailable concentration of $\mathrm{Cu}$ that causes the LC50 for D. magna should be 7.09 and $12.05 \mu \mathrm{g} / \mathrm{L}$ from Equations 2 and 3, respectively. In Equation 4, the LC50 or bioavailable concentration of $\mathrm{Cu}$ in the absence of alkalinity and FA should be $11.79 \mu \mathrm{g} / \mathrm{L}$, which was quite similar to those in Equations 1 and 3. In addition, from Equation 4, the influence of FA on toxicity is 83 -fold greater than that of alkalinity.

In our model, $\left[\mathrm{Cu}^{*}\right]$ in test solution consists of inorganic species other than $\mathrm{CuCO}_{3}$ aq and $\mathrm{CuHCO}_{3}{ }^{+}$. By definition,
LC50s could be expressed as the total spiked concentration of $\mathrm{Cu}\left(\left[\mathrm{Cu}_{\mathrm{T}}\right]\right)$, concentration of free-ion $\mathrm{Cu}\left(\left[\mathrm{Cu}^{2+}\right]\right)$, and $\left[\mathrm{Cu}^{*}\right]$. The expressions are illustrated in Figure 1. The LC50 expressed as $\left[\mathrm{Cu}_{\mathrm{T}}\right]$ is a function of alkalinity and organic components. However, LC50s expressed as either $\left[\mathrm{Cu}^{2+}\right]$ or $\left[\mathrm{Cu}^{*}\right]$ could give a constant value, independent of variation in alkalinity and organic components. In fact, $\left[\mathrm{Cu}^{2+}\right]$ was proportional to $\left[\mathrm{Cu}^{*}\right]$ under constant alkalinity. The LC50 could be predicted by FIAM or BLM models regarding $\left[\mathrm{Cu}^{2+}\right]$. However, the difficulty in using FIAM or BLM models to predict $\mathrm{Cu}$ toxicity in natural water is due to determination of the sitespecific apparent complexation constant for $\mathrm{Cu}-\mathrm{DOC}$ or $\mathrm{Cu}$ FA complexes. Therefore, we could use [Cu*] to predict the acute toxicity of $\mathrm{Cu}$ on $\mathrm{D}$. magna. By excluding $\mathrm{Cu}$-carbonate complexes from the labile concentration, $\left[\mathrm{Cu}^{*}\right]$ was obtained and used to predict the acute toxicity of $\mathrm{Cu}$ on D. magna. By performing a DAM-DPASV measurement on natural water sample, the labile concentration of $\mathrm{Cu}$ was obtained, which consists mainly of inorganic $\mathrm{Cu}$ species. The value of $\left[\mathrm{Cu}^{*}\right]$ could be obtained by exclusion of $\mathrm{Cu}$-carbonate complexes using MINTEQ A2 calculation based on measured composition of anions in the waters.

The available toxicity data (except in cases where mortality was $<10 \%$ or $>90 \%$ ) obtained from laboratory experiments with different concentrations of $\mathrm{NaHCO}_{3}$, EDTA, and FA were transformed into TP, and the relationship between TP and $\left[\mathrm{Cu}^{*}\right]$ was obtained by linear regression analysis (Fig. 3). The regression equation could be used in predicting $\mathrm{Cu}$ toxicity in natural water, where mortality can hardly be exactly $50 \%$ :

$$
\begin{array}{r}
\mathrm{TP}=2.86 \log \left[\mathrm{Cu}^{*}\right](\mu \mathrm{g} / \mathrm{L})+1.75 \\
\left(r^{2}=0.4695, n=28\right)
\end{array}
$$

\section{Measuring water-quality parameters and acute toxicity}

The $\mathrm{pH}$, concentrations of cations and anions, concentrations of heavy metal pollutants, and concentration of DOC (mg-C/L) in Le An River waters are shown in Tables 1 and 2. The copper concentration was highest at site L04 $(73.2 \mu \mathrm{g} /$ L) but lower at site L06 (16.6 $\mu \mathrm{g} / \mathrm{L})$. Previous investigation indicated that, among heavy metals, aqueous concentrations of $\mathrm{Cu}, \mathrm{Pb}$, and $\mathrm{Zn}$ during the dry season [15] and of $\mathrm{Cu}$ during the rainy season [26] exceeded the environmental quality standards for surface water (GB 3838-88, China).

The regional backgrounds of metals in Le An River sediments were 34,117 , and $45 \mathrm{mg} / \mathrm{kg}$ for $\mathrm{Pb}, \mathrm{Zn}$, and $\mathrm{Cu}$, respectively. Accordingly, the Le An River sediments were heavily polluted by heavy metals (Table 3). Metals that had sediment concentrations significantly greater than their background levels were $\mathrm{Zn}, \mathrm{Pb}$, and especially, $\mathrm{Cu}$. At site L04, the concentration of $\mathrm{Cu}$ reached $2,878 \mathrm{mg} / \mathrm{kg}$ (the highest lev$\mathrm{el}$ ), and at site $\mathrm{L} 07$, the concentration of $\mathrm{Cu}$ was $1,012 \mathrm{mg}$ / $\mathrm{kg}$.

In most of the natural freshwaters, $\mathrm{Cu}$ was mainly bound to organic substances [12]. Because of the presence of naturally derived organic matter, the DPASV labile concentrations of $\mathrm{Cu}$ could not be directly measured in water samples from several other locations (data not shown). The DAM was applied to eliminate the effects of complexing agents on the ASV process and of surfactants on both deposition and stripping processes in natural water [14]. The labile concentration of $\mathrm{Cu}$ was obtained from the measured stripping current in DAMDPASV. From the labile concentration, the bioavailable concentrations of $\mathrm{Cu}$ could be obtained. 
Table 3. Concentrations (mg/kg dry wt) of $\mathrm{Cu}, \mathrm{Pb}$, and $\mathrm{Zn}$ in sediments from different sampling sites in the Le An River (Jiangxi Province, China)

\begin{tabular}{lrrrrrrrr}
\hline & \multicolumn{9}{c}{ Sampling site } \\
\cline { 2 - 9 } Element & L01 & L02 & \multicolumn{1}{c}{ L04 } & \multicolumn{1}{c}{ L05 } & L06 & L07 & L08 & L09 \\
\hline $\mathrm{Cu}$ & 36 & 215 & 2,878 & 2,173 & 1,788 & 1,012 & 733 & 523 \\
$\mathrm{~Pb}$ & 44 & 81 & 42 & 44 & 29 & 208 & 94 & 68 \\
$\mathrm{Zn}$ & 117 & 226 & 221 & 201 & 202 & 878 & 664 & 451 \\
\hline
\end{tabular}

Results of the acute toxicity bioassays for the Le An River waters are shown in Table 4 . The river water was slightly toxic at site L04 (mortality, 6.7\%) and extremely toxic at site L06 (mortality, 100\%). Mortality predicted by the bioavailable concentration of $\mathrm{Cu}$ using Equation 5 was quite consistent with that measured using bioassays for Le An River waters (Table 4). At sites L01 to L05 and L07 to L09, toxicities could be neither measured nor predicted, because the mortality of less than $10 \%$ was considered to be insignificant.

Because the highest concentration of $\mathrm{Cu}$ was observed at site L04, not at site L06, some other factors should affect the toxicity to D. magna. Among these factors, concentration of DOC was the highest at site L04 (3 mg/L), whereas it was undetectable at site L06. Consequently, the highest labile concentration of $\mathrm{Cu}(14.7 \mu \mathrm{g} / \mathrm{L})$ was observed at site L06, not at site L04. The influence of DOC appears to be responsible for the reduced toxicity at site L04. A mortality of $100 \%$ occurred at site L06, where a mortality of $45 \%$ was predicted based on the toxicity of $\mathrm{Cu}$. The observed toxicity at site L06 could also be caused by the joint toxic effect of $\mathrm{Cu}$ and $\mathrm{Zn}$. The toxic equivalent of $\mathrm{Zn}$ at site L06 was 2.6, as calculated from the measured concentration of Zn divided by its LC50 (540 $\mu \mathrm{g} / \mathrm{L}$ in reconstituted water). The toxic equivalent of $\mathrm{Cu}$ (LC50 $=13.6 \mu \mathrm{g} / \mathrm{L}$ in reconstituted water) was 1.98 , which was similar to that of $\mathrm{Zn}$. The influences of other metals on toxicity could be negligible.

Sediments from different sampling sites were used to obtain sediment elutriates, and elutriates were used for acute bioassay and DAM-DPASV measurements. The experiment could simulate the sediment toxicity under aerobic conditions. The total dissolved and labile concentration of $\mathrm{Cu}$ in sediment elutriate from the Le An River and the observed toxicity to D. magna are shown in Table 5. The toxicity to D. magna was predicted from the $\left[\mathrm{Cu}^{*}\right]$ (Table 5). As shown in Table 5, both the highest soluble and bioavailable concentrations of $\mathrm{Cu}$ occurred at site L07, and both measured and predicted toxicities indicated a mortality of $100 \%$ at this site. A mortality of $87 \%$ was also observed in sediment elutriate from site L06, where only moderate mortality $(19 \%)$ was predicted based on the measured $\left[\mathrm{Cu}^{*}\right]$.

The concentration of $\mathrm{Cu}$ in sediment from site L07 was lower than that from site L06 (Table 3), whereas the total dissolved and labile concentration of $\mathrm{Cu}$ from site L07 was higher. This indicates that $\mathrm{Cu}$ bound to sediment at site L07 was more mobile and bioavailable and that the sediment toxicity could hardly be predicted by its total metal concentration. This suggests that both mobility and bioavailability be taken into account.

To obtain the LC50 of sediment elutriate from site L07, elutriate was sequentially diluted for bioassay. The results of toxic bioassay and DAM-DPASV measurement for $50 \%$ sequential dilution of sediment elutriate from site L07 are shown in Table 6. The data show both measured and predicted mortalities of D. magna with regard to $\left[\mathrm{Cu}^{*}\right]$. As can be seen, the mortality of $D$. magna in the diluted sediment elutriate could be well predicted by assuming that $\mathrm{Cu}$ was the toxicant.

From Table 6, it is quite interesting to note that the LC50 for $\left[\mathrm{Cu}^{*}\right]$ in sediment elutriate was approximately $11.64 \mu \mathrm{g} /$ $\mathrm{L}$, which is quite close to the laboratory-observed $\left[\mathrm{Cu}^{*}\right]$ that caused the LC50 in reconstituted water $(13.6 \mu \mathrm{g} / \mathrm{L})$. This indicates that the LC50 expressed as $\left[\mathrm{Cu}^{*}\right]$ to $D$. magna in freshwater was approximately $12 \mu \mathrm{g} / \mathrm{L}$, independent of waterquality variations. Similarly, the lowest-observed-effective concentration should be $2.3 \mu \mathrm{g} / \mathrm{L}$.

\section{CONCLUSIONS}

Alkalinity, EDTA, and FA have significant influences on the acute toxicity of $\mathrm{Cu}$ to $D$. magna. These influences could be

Table 4. Concentrations of different $\mathrm{Cu}$ species and predicted/observed mortality on Daphnia magna in the Le An River waters (Jiangxi Province, China)

\begin{tabular}{|c|c|c|c|c|c|}
\hline $\begin{array}{l}\text { Sampling } \\
\text { sites }\end{array}$ & $\begin{array}{l}{\left[\mathrm{Cu}_{\mathrm{T}}\right]} \\
(\mu \mathrm{g} / \mathrm{L})^{\mathrm{a}}\end{array}$ & $\begin{array}{l}{\left[\mathrm{Cu}_{\text {labile }}\right]} \\
(\mu \mathrm{g} / \mathrm{L})^{\mathrm{b}}\end{array}$ & $\begin{array}{l}{\left[\mathrm{Cu}^{*}\right]} \\
(\mu \mathrm{g} / \mathrm{L})^{\mathrm{c}}\end{array}$ & $\begin{array}{c}\text { Measured } \\
\text { mortality }(\%)^{\mathrm{d}}\end{array}$ & $\begin{array}{c}\text { Predicted } \\
\text { mortality }(\%)^{\mathrm{e}}\end{array}$ \\
\hline L01 & 5.3 & $\mathrm{ND}^{\mathrm{f}}$ & ND & ND & 0 \\
\hline L02 & 5.3 & $2.6 \pm 0.7$ & ND & ND & 0 \\
\hline L04 & 73.2 & ND & ND & $6.7 \pm 3.5$ & 0 \\
\hline L05 & 5.1 & $1.3 \pm 1.3$ & 0.6 & ND & 5 \\
\hline L06 & 16.6 & $14.7 \pm 2.5$ & 11.5 & $100 \pm 18$ & 45 \\
\hline L07 & 6.8 & $5.1 \pm 3.2$ & 3.8 & ND & 8 \\
\hline L08 & 6.8 & $5.8 \pm 1.9$ & 4.5 & ND & 3 \\
\hline L09 & 5.1 & $3.8 \pm 0.6$ & 3.2 & ND & 4 \\
\hline
\end{tabular}

${ }^{\text {a }}$ The concentration of total $\mathrm{Cu}\left(\left[\mathrm{Cu}_{\mathrm{T}}\right]\right)$ was measured by graphite furnace atomic absorption spectrometry.

${ }^{\mathrm{b}}$ The labile concentration of $\mathrm{Cu}\left(\left[\mathrm{Cu}_{\text {labile }}\right]\right)$ was measured by a differential pulse anodic stripping voltammetry with a double-acidification method

${ }^{c}$ The bioavailable concentration of $\mathrm{Cu}\left(\left[\mathrm{Cu}^{*}\right]\right)$ was calculated from $\left[\mathrm{Cu}_{\text {labile }}\right]$ and concentration of anions in water using MINTEQ A2 (developed by the U. S. Environmental Protection Agency).

d The mortality was measured on D. magna $(n=3)$.

e The mortality was predicted using Equation 5 (see text).

${ }^{\mathrm{f}} \mathrm{ND}=$ not detected. 
Table 5. Concentrations of total $\mathrm{Cu}\left(\left[\mathrm{Cu}_{\mathrm{T}}\right]\right)$ and bioavailable $\mathrm{Cu}\left(\left[\mathrm{Cu}^{*}\right]\right)$ and predicted/measured mortality on Daphnia magna in sediment elutriates down the Le An River (Jiangxi Province, China)

\begin{tabular}{lcccc}
\hline $\begin{array}{l}\text { Sampling } \\
\text { sites }\end{array}$ & {$\left[\mathrm{Cu}_{\mathrm{T}}\right](\mu \mathrm{g} / \mathrm{L})^{\mathrm{a}}$} & {$\left[\mathrm{Cu}^{*}\right](\mu \mathrm{g} / \mathrm{L})^{\mathrm{b}}$} & $\begin{array}{c}\text { Predicted } \\
\text { mortality }(\%)^{\mathrm{c}}\end{array}$ & $\begin{array}{c}\text { Measured } \\
\text { mortality }(\%)^{\mathrm{d}}\end{array}$ \\
\hline L01 & $\mathrm{ND}^{\mathrm{e}}$ & $\mathrm{ND}$ & 0 & $\mathrm{ND}$ \\
L04 & 3.8 & $2.6 \pm 1.3$ & 1 & $7 \pm 3$ \\
L06 & 7.7 & $6.4 \pm 1.3$ & 19 & $87 \pm 12$ \\
L07 & 249.8 & $152.9 \pm 19.2$ & 100 & $100 \pm 21$ \\
L08 & 7.1 & $4.5 \pm 1.3$ & 8 & $27 \pm 7$ \\
L09 & 9.6 & $5.8 \pm 3.2$ & 13 & $7 \pm 5$ \\
\hline
\end{tabular}

${ }^{a}$ Measured by graphite furnace atomic absorption spectrometry.

${ }^{b}$ Calculated from $\left[\mathrm{Cu}_{\text {labile }}\right]$ and measured alkalinity in elutriate (data not shown).

${ }^{c}$ The mortality was measured on D. magna $(n=3)$.

d The mortality was predicted using Equation 5 (see text).

e ND $=$ not detected.

excluded by defining the bioavailable concentration of $\mathrm{Cu}$, or $\left[\mathrm{Cu}^{*}\right]$, which could be obtained by a DAM-DPASV measurement and a calibration to exclude $\mathrm{Cu}$-carbonate complexes from labile $\mathrm{Cu}$ species. The relationship between $\left[\mathrm{Cu}^{*}\right]$ and toxicity to $D$. magna could be formulated through laboratory simulation experiments in the presence of $\mathrm{NaHCO}_{3}$, EDTA, and FA. This relationship could be then be applied to predict the acute toxicity of $\mathrm{Cu}$ in the natural water and sediment elutriates from a river that has been severely polluted by a copper mine. The bioavailable concentration of $\mathrm{Cu}$ that causes $50 \%$ of mortality on D. magna, both in the laboratory experiments and under field conditions, was approximately $12 \mu \mathrm{g} / \mathrm{L}$.

The proposed procedure provides an alternative to the FIAM model. Furthermore, the bioavailable concentration of $\mathrm{Cu}$, or $\left[\mathrm{Cu}^{*}\right]$, was used to replace the free-ion activity in the prediction of toxicity. The information presented in this paper provides a means to measure the bioavailable concentration of $\mathrm{Cu}$ in natural water by combining DAM-DPASV measurement and a model calculation to exclude the influences of $\mathrm{Cu}$ carbonate complexes.

Acknowledgement-This study was supported by the International Copper Association (TP0602) and partially supported by the Chinese Academy of Sciences (KZCX2-410). The authors would like to acknowledge the valuable support and useful discussion from Herbert Allen from the University of Delaware, Newark, Delaware, USA. Thanks are also due to Shahamat U. Khan of George Mason University, Fairfax, VA, USA, for carefully revising the manuscript.

Table 6. Concentrations of bioavailable $\mathrm{Cu}\left(\left[\mathrm{Cu}^{*}\right]\right)$ and predicted/ measured mortality on Daphnia magna in the sequential dilutions of elutriate from site L07 in Le An River (Jiangxi Province, China)

\begin{tabular}{lccc}
\hline $\begin{array}{l}\text { Dilution } \\
\text { proportion }\end{array}$ & {$\left[\mathrm{Cu}^{*}\right](\mu \mathrm{g} / \mathrm{L})^{\mathrm{a}}$} & $\begin{array}{c}\text { Predicted } \\
\text { mortality }(\%)^{\mathrm{b}}\end{array}$ & $\begin{array}{c}\text { Measured } \\
\text { mortality }(\%)^{\mathrm{c}}\end{array}$ \\
\hline $1 / 1$ & $152.9 \pm 19.2$ & 100 & $100 \pm 21$ \\
$1 / 2$ & $98.6 \pm 14.7$ & 100 & $100 \pm 12$ \\
$1 / 4$ & $49.3 \pm 8.3$ & 95 & $100 \pm 34$ \\
$1 / 8$ & $23.7 \pm 5.8$ & 75 & $67 \pm 10$ \\
$1 / 16$ & $9.6 \pm 4.5$ & 44 & $47 \pm 8$ \\
$1 / 32$ & $6.4 \pm 2.6$ & 18 & $20 \pm 6$ \\
\hline
\end{tabular}

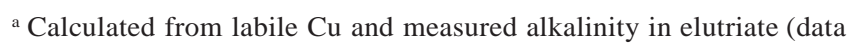
not shown)

${ }^{\text {b }}$ The mortality was measured on D. magna $(n=3)$.

${ }^{\mathrm{c}}$ The mortality was predicted using Equation 5 (see text).

\section{REFERENCES}

1. Allen HE, Hansen DJ. 1996. The importance of trace metal speciation to water quality criteria. Water Environ Res 68:283-295.

2. Allen HE. 1993. The significance of trace speciation for water, sediment and soil quality standards. Sci Total Environ 134:2334.

3. Campbell PGC. 1995. Interactions between trace metals and aquatic organisms. In Tessier A, Turner DR, eds, Metal Speciation and Bioavailability in Aquatic System. John Wiley, New York, NY, USA, pp 45-102.

4. Morel FMM, Hering J. 1993. Principles and Applications of Aquatic Chemistry. John Wiley, New York, NY, USA.

5. Morel FMM. 1983. Principles of Aquatic Chemistry. John Wiley, New York, NY, USA. p 301.

6. Erickson RJ, Benoit DA, Mattson VR. 1996. The effects of water chemistry on the toxicity of copper to fathead minnows. Environ Toxicol Chem 15:181-193.

7. Playle RC, Gensemer RW, Dixon DG. 1992. Copper accumulation on gills of fathead minnows: Influence of water hardness, complexation and $\mathrm{pH}$ on the gill microenvironment. Environ Toxicol Chem 11:381-391.

8. U.S. Environmental Protection Agency. 1999. Integrated approach to assessing the bioavailability and toxicity of metals in surface waters and sediments. EPA-822-E-99-001. Technical Report. Office of Water, Washington, DC.

9. Mayer JS, Santore RC, Bobbitt JP. 1999. Binding of nickel and copper to fish gills predicts toxicity when water hardness varies, but free ion activity does not. Environ Sci Technol 33:913-916.

10. U.S. Environmental Protection Agency. 2000. Review of the biotic ligand model of the acute toxicity of metals. EPA-SABEPEC-00-006. Final Report. The Ecological Processes and Effects Committee of the Science Advisory Board, Washington, DC.

11. Florence TM. 1986. Electrochemical approaches to trace element speciation in waters: A review. Analyst 111:489-505.

12. Morrison GM, Florence TM, Stauber JL. 1990. The effects of complexing agents and surfactants on the deposition and stripping processes in DPASV of metals. Electroanalysis 2:9-14.

13. Florence TM, Morrison GM, Stauber JL. 1992. Determination of trace element speciation and the role of speciation in aquatic toxicity. Sci Total Environ 125:1-13.

14. Florence TM. 1992. Trace element speciation by anodic stripping voltammetry. Analyst 117:551-553.

15. He MC, Wang Z, Tang HX. 1998. The chemical, toxicological and ecological studies in assessing the heavy metal pollution in Le An River, China. Water Res 32:510-518.

16. He MC, Wang Z, Tang HX. 1997. Spatial and temporal pattern of acidity and heavy metals in predicting the potential for ecological impact on the Le An river polluted by acid mine drainage. Sci Total Environ 206:67-77.

17. Wang Z. 1999. Major environmental and ecotoxicological processes of heavy metals in Le An River polluted by discharges from mining activities. Chin J Environ Sci 11:322-327.

18. Wang Z. 1987. Interaction between heavy metals and humic acidquarsi- particle surface complexation model. Acta Scientiae Circumstantiae (China) 7:313-318. 
19. Vasconcelos MT, Azenha MA, Lage O, 1996. Electrochemical evidence of surfactant activity of the Hepes $\mathrm{pH}$ buffer which may have implication on trace metal availability to culture in vitro. Anal Biochem 241:248-253.

20. Wen XH, Wu LZ, Zhang Y. 1997. Optimized microwave preparation procedure for the elemental analysis of aquatic sediment. Fresenius J Anal Chem 357:1111-1115.

21. U.S. Environmental Protection Agency. 1975. Methods for acute toxicity tests with fish, macroinvertebrates, and amphibians. EPA660/3-75/009. Washington, DC.

22. Hamilton MA, Russo RC, Thurston RV. 1977. Trimmed Spearman-Karber method for estimating median lethal concentrations in toxicity bioassays. Environ Sci Technol 11:714-719, Correction 12:417 (1978).

23. Zhou YX, Zhang ZS. 1989. Methods For Aquatic Bioassays. Agricultural Publishing House, Beijing, China.

24. Wang Z, Stumm W. 1987. Heavy metal complexation by surfaces and humic acids: A brief discourse on assessment by acidimetric titration. Neth J Agric Sci 35:231-240.

25. Deaver E, Rodgers JH. 1996. Measuring bioavailable copper using anodic stripping voltammetry. Environ Toxicol Chem 15: $1925-1930$

26. Wang Z, Ma M, Du Q. 1994. Toxicity assessment by photobacterium phosphoreum. China J Environ Sci 5:159-164. 